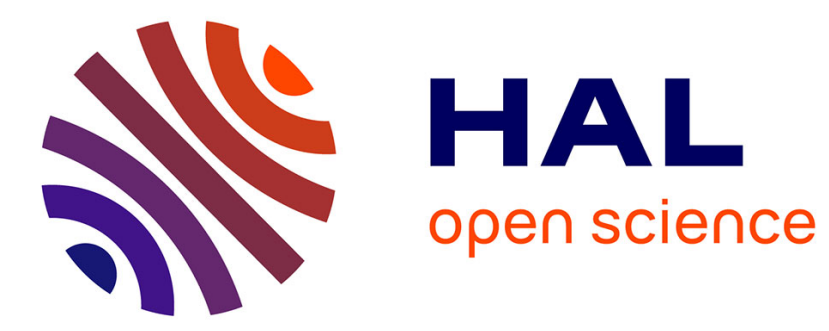

\title{
Endocrine actions of cortistatin: In vivo studies
}

Fabio Broglio, Silvia Grottoli, Emanuela Arvat, Ezio Ghigo

\section{To cite this version:}

Fabio Broglio, Silvia Grottoli, Emanuela Arvat, Ezio Ghigo. Endocrine actions of cortistatin: In vivo studies. Molecular and Cellular Endocrinology, 2008, 286 (1-2), pp.123. 10.1016/j.mce.2007.12.012 . hal-00531976

\section{HAL Id: hal-00531976 https://hal.science/hal-00531976}

Submitted on 4 Nov 2010

HAL is a multi-disciplinary open access archive for the deposit and dissemination of scientific research documents, whether they are published or not. The documents may come from teaching and research institutions in France or abroad, or from public or private research centers.
L'archive ouverte pluridisciplinaire $\mathbf{H A L}$, est destinée au dépôt et à la diffusion de documents scientifiques de niveau recherche, publiés ou non, émanant des établissements d'enseignement et de recherche français ou étrangers, des laboratoires publics ou privés. 


\section{Accepted Manuscript}

Title: Endocrine actions of cortistatin: In vivo studies

Authors: Fabio Broglio, Silvia Grottoli, Emanuela Arvat, Ezio

Ghigo

PII: $\quad$ S0303-7207(07)00477-7

DOI: $\quad$ doi:10.1016/j.mce.2007.12.012

Reference: $\quad$ MCE 6776

To appear in: $\quad$ Molecular and Cellular Endocrinology

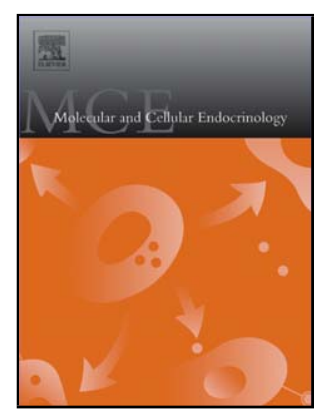

Received date:

20-8-2007

Revised date:

$11-12-2007$

Accepted date:

$18-12-2007$

Please cite this article as: Broglio, F., Grottoli, S., Arvat, E., Ghigo, E., Endocrine actions of cortistatin: In vivo studies, Molecular and Cellular Endocrinology (2007), doi:10.1016/j.mce.2007.12.012

This is a PDF file of an unedited manuscript that has been accepted for publication. As a service to our customers we are providing this early version of the manuscript. The manuscript will undergo copyediting, typesetting, and review of the resulting proof before it is published in its final form. Please note that during the production process errors may be discovered which could affect the content, and all legal disclaimers that apply to the journal pertain. 
Endocrine actions of cortistatin: in vivo studies

Fabio Broglio, Silvia Grottoli, Emanuela Arvat, Ezio Ghigo

Division of Endocrinology and Metabolism, Department of Internal Medicine; University of Turin, Italy

Short title: in vivo cortistatin actions

\section{Address correspondence to:}

F. Broglio, MD, PhD; Division of Endocrinology and Metabolism; Department of Internal Medicine; University of Turin; C.so Dogliotti 14; 10126 Torino; Italy ; Phone: +39.011 .6334317 ;

Fax: +39.011.6647421 ; E-Mail: fabio.broglio@unito.it 
Key words: cortistatin, somatostatin, GH, insulin, PRL, ACTH, cortisol

\begin{abstract}
Cortistatin (CST) shares high structural homology with somatostatin (SST) and binds all SSTreceptors (SST-R) subtypes with similar affinity. However, CST actions, tissue expression patterns and regulation do not fully overlap with those of SST, and, moreover, CST, but not SST, also binds and activates proadrenomedullin N-terminal peptide receptor (MrgX2) and shows binding affinity to ghrelin receptor (GHS-R1a). Several studies performed to clarify the endocrine actions of CST, compared with SST, showed that, in humans, CST and SST share the same endocrine actions, i.e. inhibition of GH and insulin secretion in physiological conditions and in acromegaly. A similar inhibitory effect on PRL and ACTH secretion was shown in acromegaly, prolactinoma or in Cushing's disease. This identity of endocrine actions by CST and SST suggests that SST-R activation by CST overrides any other independent action of this peptide mediated by other receptors. Thus, in terms of endocrine actions, CST can well be considered a natural alternative to SST.
\end{abstract}




\section{Introduction}

Cortistatin (CST) is a novel neuropeptide cloned from frog, rat, mouse and human tissues (de Lecea et al ., 1996; Tostivint et al ., 1996). Like pro-somatostatin (SST), pro-CST generates multiple mature products, i.e. CST-14 and CST-29 in rat and CST-17 and CST-29 in human (Fukusumi et al ., 1997; Spier \& de Lecea, 2000). In correspondence with their pre-pro-molecules, the CST and SST mature products are highly structurally homologous and both of them bind all the known five SST receptor (SST-R) subtypes with similar affinity (Fukusumi et al ., 1997; Spier \& de Lecea, 2000).

The similarities in their chemical structures and in the binding affinity to SST-R as well as a compensatory increase of CST expression in SST-KO mice reported by some (Cammalleri et al ., 2006; Luque \& Kineman ., 2007), though not by all the Authors (Low et al ., 2001; Zeyda et al ., 2001; Ramirez et al ., 2002), might suggest that CST is an alternative SST. However, several evidence clearly indicate that CST and SST possess distinct identities. In fact, 1) CST and SST are encoded by different genes (de Lecea et al ., 1997b); 2) the areas in the central nervous system expressing these neuropeptides are similar but not overlapping (de Lecea et al ., 1997a); 3) when co-expressed in the same neurons, CST and SST are regulated by different signals (Calbet et al ., 1999; Stumm et al ., 2004); 4) peripheral CST expression does not parallel that of SST (Dalm et al ., 2004); and 5) although CST and SST share some central biological actions, CST also possesses distinct activities e.g. in the modulation of sleep physiology, locomotor behaviour and hippocampal functions (Spier \& de Lecea., 2000). These differences suggested the existence of specific and selective CST receptors (de Lecea \& Castano ., 2006).

Based on evidence that CST and SST display identities and differences, it appears of major interest to clarify the endocrine actions of CST. This paper reviews the studies performed so far in order to clarify this intriguing aspect.

\section{The CST system}

CST expression was originally described in the central nervous system, in particular in the cortex and in the hippocampus while only a weak signal was reported in the hypothalamus (Patel ., 1999; Spier \& de Lecea, 2000). Co-localization studies showed that CST is expressed in GABAergic interneurons (de Lecea et al ., 1997a; Spier \& de Lecea, 2000) but less than half of the CST expressing neurons also contain SST, and approximately a quarter of SST containing cells expresses CST mRNA (Spier \& de Lecea, 2000). More recently, CST mRNA was shown in peripheral tissues including adrenal, thyroid, pancreas, testes, liver, stomach, ileum, jejunum, colon, 
rectum, kidney and lung as well as in the chief cells of the parathyroid and in the immune cells; in some of these tissues e.g. parathyroid and immune cells, SST is not expressed (Papotti et al ., 2003; Dalm et al ., 2004; Allia et al ., 2005; Xidakis et al ., 2007). Despite several reports about CST mRNA expression in various central and peripheral tissues (Spier \& de Lecea, 2000), information about CST protein distribution in normal and in neoplastic tissues has been provided only recently by Papotti et al (Papotti et al ., 2003; Allia et al ., 2005; Cassoni et al ., 2006). CST protein synthesis has been reported in the cytoplasm of neuronal cells of the cerebral cortex and hypothalamus, in neuroendocrine pituitary cells, and in the neuroendocrine cells of the pancreatic islets and of the gastrointestinal tract, in particular in the $\delta$ cells (Papotti et al ., 2003; Allia et al ., 2005). Despite positive RT-PCR results, no immunoreactivity for CST was found in the lung, ovary, thyroid, testis, and adrenal, neither in neuroendocrine nor in non-neuroendocrine cell types (Allia et al ., 2005).

CST peptide and mRNA expression have also been investigated in neoplastic tissues (Allia et al ., 2005). Specific CST mRNA was detected in phaeochromocytomas, parathyroid adenomas, nonfunctioning pancreatic endocrine tumors, and neuroendocrine tumors of the lung, of the gastrointestinal tract as well as in the functioning neuroendocrine tumors of the pancreas. The majority of the neuroendocrine tumors that contained CST mRNA by RT-PCR were also CST positive by immunohistochemistry, with the exception of parathyroid adenoma and Merkel cell carcinoma, which showed no immunoreactivity. In the non-neuroendocrine tumor group, a weak mRNA signal was present in adenocarcinomas of the lung, stomach, and colon, and in follicular tumors of the thyroid. By contrast, CST immunohistochemistry failed to demonstrate immunoreactive cells in any of the non neuroendocrine tumors (Allia et al ., 2005).

As anticipated, all CST forms bind all the known five SST-R with an affinity in the low nanomolar range similar to that of SST (Spier \& de Lecea, 2000). The so called SST-R are a family of five G-protein coupled receptor subtypes $\left(\mathrm{SST}_{\left.-\mathrm{R}_{1-5}\right)}\right.$ ) encoded on different chromosomes (Patel ., 1999; Moller et al ., 2003). SST-R genes are expressed in the brain and periphery, and mediate SST activities including neurotransmission, neuromodulation, regulation of endocrine and exocrine secretions, and inhibition of tumor growth (Patel ., 1999; Moller et al ., 2003).

The existence of multiple SST-R subtypes as well as of SST forms does not simply reflect a highly redundant system; in fact, the selective activation of each subtype provides a unique biologic effect, a consequence not only of distinct (though partially overlapping) tissue distributions but also of different functional regulations and intracellular signaling (Patel ., 1999; Moller et al ., 2003).

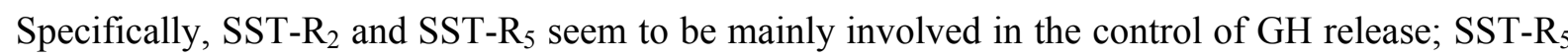
seems to play a role in controlling insulin and glucagon secretion; SST-R 3 and to a lesser extent 


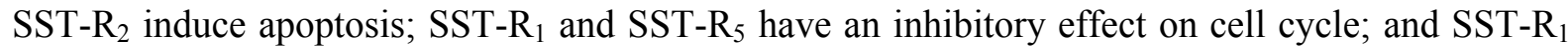
seems to be involved in angiogenesis (Patel ., 1999; Moller et al ., 2003). To better understand the specific biological effects mediated by the SST-R family, several synthetic selective SST-R agonists have been generated. Among those with clinical relevance, octreotide, lanreotide, and vapreotide bind with high affinity to SST- $\mathrm{R}_{2}$, and, to a lesser extent, to SST- $\mathrm{R}_{5}$, have a low affinity for SST-R 3 , and do not bind to SST-R ${ }_{1}$ and SST-R (Patel ., 1999; Moller et al ., 2003). More recently, SOM-230 has been presented as "universal" ligand able to bind all the five receptor subtypes, though SST-R 4 with significantly lower affinity (Boerlin et al ., 2003).

More recently, $\mathrm{MrgX2}$, a previously orphan receptor mainly expressed in dorsal root ganglions has also been reported to bind CST but not SST (Robas et al ., 2003). Surprisingly, MrgX2, which is also bound by proadrenomedullin N-terminal peptide (PAMP) (an endogenous peptide with powerful hypotensive actions (Kamohara et al ., 2005), is not expressed in the cerebral cortex, where CST is most abundant (Robas et al ., 2003). The biological role of CST binding to MrgX2 therefore remains unclear although it is suggested to modulate pain perception (Robas et al ., 2003). More recently, CST, but not SST, has been shown able to displace iodinated, acylated ghrelin from its specific binding sites (putatively the GHS-R1a) (Muccioli et al ., 2001; Deghenghi et al ., 2001b; Deghenghi et al ., 2003). However, direct in vitro evidence of CST binding and activation of the GHSR-1a (i.e. in transfected cells) is lacking. Nevertheless, competition between CST and acylated ghrelin or its synthetic analogues (Muccioli et al ., 2001; Deghenghi et al ., 2001b; Deghenghi et al ., 2003; Allia et al ., 2005) (the specific binding of which to GHSR-1a has been clearly demonstrated (Smith et al ., 2001; Deghenghi et al ., 2003; Van Der Lely et al ., 2004)) for specific binding to GHSR-1a suggested that CST could represent another endogenous GHSR-1a ligand. Interestingly, CST displaces radio-iodinated ghrelin from pituitary binding sites at concentrations ten-fold greater than that required to inhibit the binding of radiolabelled SST to its receptors (Sibilia et al ., 2006).

\section{Endocrine actions of cortistatin}

\section{$\underline{\text { Studies in vitro }}$}

In isolated pig somatotroph CST and SST possess the same dual, inhibitory and stimulatory effects on GH release (Luque et al ., 2006b). Similarly, CST like SST is a potent suppressor of GH secretion in human fetal pituitary cells and GH-cell adenomas (Rubinfeld et al ., 2006). Also, CST inhibits PRL secretion from prolactinomas and mixed GH/PRL pituitary tumors; this is likely 
mediated via SST-R 5 , as indicated by the lack of any inhibitory effect in prolactinomas without SST-R ${ }_{5}$ expression (Rubinfeld et al ., 2006).

\section{$\underline{\text { Studies in animals in vivo }}$}

The number of in vivo studies in animals focusing on the endocrine CST actions is very limited. CST has been demonstrated to inhibit dose dependently GH secretion in anesthetized rats (Deghenghi et al ., 2001a). The inhibitory effect of CST was compared with that of SST and was found to be overlapping; based on this evidence it was concluded that both peptides exert inhibitory effect on somatotroph function mediated by the activation of the same SST-R subtypes (Deghenghi et al ., 2001a; Luque et al ., 2006b).

\section{$\underline{\text { Studies in humans in vivo }}$}

Normal subjects: In normal healthy volunteers the effects of either CST-14 or CST-17 on GH and insulin secretion as well as on glucose levels have been evaluated and compared with those of native SST (Broglio et al ., 2002a; Broglio et al ., 2002b; Benso et al ., 2003; Gottero et al ., 2004); CST inhibited to the same extent GH and insulin secretion without any significant effect on glucose levels. Similarly, it has been demonstrated that CST and SST share the same inhibitory effect on the GH response to either GHRH or ghrelin or its synthetic analogues (Broglio et al ., 2002a; Benso et al ., 2003; Gottero et al ., 2004). Also, CST as well as SST did not affect the PRL, ACTH and cortisol responses to the acute ghrelin administration (Broglio et al ., 2002a). On the other hand, it has been shown that CST and SST display the same inhibitory effect of ghrelin secretion in humans (Broglio et al ., 2002b).

Acromegaly and prolactinomas: A study (Grottoli et al ., 2006) compared the endocrine effects of cortistatin-17 with those of somatostatin-14 in 15 patients with acromegaly or prolactinomas. CST and SST inhibited GH secretion to the same extent in acromegalics like in normal controls; the same effect was recorded also in patients with prolactinomas in whom, however, the low basal GH values were not significantly reduced by both peptides. Moreover, both CST and SST inhibited PRL secretion in acromegaly and prolactinoma patients but not in normal subjects. Insulin secretion was inhibited by both CST and SST to the same extent in acromegaly and prolactinoma patients as well as in controls. Glucose levels did not change during CST or SST infusion in any group. No patient showed any response to CST that was not shared by SST. This study, therefore, 
demonstrated that CST is really unlikely to differ from SST in terms of endocrine actions, likely acting via the activation of the same SST-R subtypes.

Cushing's disease: Another study (Giordano et al ., 2007) compared the endocrine effects of CST and SST in 9 patients with Cushing's disease (CD). Either SST or CST significantly affected Hypothalamus-Pituitary-Adrenal (HPA) axis in CD patients but not in normal controls. In CD, cortisol secretion was decreased to the same extent by either SST or CST. Both SST and CST decreased mean ACTH secretion, although statistical difference was reached during CST infusion only. Analyzing the individual responses, in CD patients clear-cut and consensual inhibition of both ACTH and cortisol under either SST or CST was recorded in 5/9 patients. In CD, as well as in controls, either SST and CST inhibited insulin secretion and insulin levels rebounded at the end of the infusion. Differently from controls, in $\mathrm{CD}$, the very low basal GH levels were not further significantly reduced by either CST or SST.

These results are consistent with the data already available in the literature on the role of SST in the regulation of the HPA axis. In fact, in vivo studies in normal subjects have shown that SST does not affect basal ACTH levels or the ACTH response to CRF, suggesting that it does not normally act at the pituitary level to regulate corticotroph function (Engler et al ., 1999). Similarly, no change in ACTH secretion of patients with Cushing's disease has been observed in some studies where either native SS or octreotide were administered acutely (Ambrosi et al ., 1990; Lamberts et al ., 1991; Stalla et al ., 1994). Octreotide was instead reported able to exert some inhibitory effect on ACTH levels in other ACTH hypersecretory states, such as in Addison's disease and in Nelson's syndrome (Tyrrell et al ., 1975; Fehm et al ., 1976; Lamberts et al ., 1989). Notably, however, in SST-KO mice corticosterone levels have been reported to be increased, associated with a significant rise in pituitary POMC expression, thus suggesting that, at least in the mouse, endogenous SST can act as a corticotropic synthesis/release-inhibiting factor (Luque et al ., 2006a). Consistently with the different results in vivo, the in vitro studies have shown that the effects of SST on ACTH secretion are critically dependent upon the use of normal or neoplastic pituitary tissue and on the presence or absence of glucocorticoids in the incubation medium (Engler et al ., 1999)

\section{Conclusions}

Cortistatin, a natural somatostatin analogue, shares with somatostatin the same endocrine actions i.e. mostly inhibition of GH and insulin secretion in either physiological and pathological conditions 
such as acromegaly. Some similar inhibitory effects of CST and SST on PRL and ACTH secretion have also been recorded in hyperprolactinemic acromegaly, prolactinoma and Cushing's disease. This identity of endocrine actions exerted by CST and SST is likely to indicate that SST receptor subtype activation by CST overrides any other independent action of this peptide mediated by other receptors. Thus, in term of endocrine actions, CST can well be considered a natural alternative to SST. 


\section{Acknowledgements:}

The Authors wish to thank Dr. A. Benso, P. Cassoni, R. Deghenghi, V. Gasco, C. Ghè, R. Giordano, C. Gottero, and F. Prodam for their participation in the personal studies described in the present review. 


\section{References}

Allia, E., Tarabra, E., Volante, M., Cerrato, M., Ghigo, E., Muccioli, G., Papotti, M., 2005. Expression of cortistatin and $\mathrm{MrgX} 2$, a specific cortistatin receptor, in human neuroendocrine tissues and related tumours. J.Pathol. 207, 336-345.

Ambrosi, B., Bochicchio, D., Fadin, C., Colombo, P., Faglia, G., 1990. Failure of somatostatin and octreotide to acutely affect the hypothalamic-pituitary-adrenal function in patients with corticotropin hypersecretion. J.Endocrinol.Invest 13, 257-261.

Benso, A., Gottero, C., Prodam, F., Gauna, C., Destefanis, S., Filtri, L., Van Der Lely, A.J., Deghenghi, R., Ghigo, E., Broglio, F., 2003. Effects of cortistatin-14 and somatostatin-14 on the endocrine response to hexarelin in humans. J.Endocrinol.Invest 26, 599-603.

Boerlin, V., van der, H.J., Beglinger, C., Poon, K.W., Hartmann, S., Dutreix, C., Kovarik, J.M., Bruns, C., Weckbecker, G., Lewis, I., Schnieper, P., Hofland, L.J., Lamberts, S.W., 2003. New insights on SOM230, a universal somatostatin receptor ligand. J.Endocrinol.Invest 26, 14-16.

Broglio, F., Arvat, E., Benso, A., Gottero, C., Prodam, F., Grottoli, S., Papotti, M., Muccioli, G., Van Der Lely, A.J., Deghenghi, R., Ghigo, E., 2002a. Endocrine activities of cortistatin-14 and its interaction with GHRH and ghrelin in humans. J.Clin.Endocrinol.Metab 87, 3783-3790.

Broglio, F., Koetsveld, P.P., Benso, A., Gottero, C., Prodam, F., Papotti, M., Muccioli, G., Gauna, C., Hofland, L., Deghenghi, R., Arvat, E., Van Der Lely, A.J., Ghigo, E., 2002b. Ghrelin secretion is inhibited by either somatostatin or cortistatin in humans. J.Clin.Endocrinol.Metab 87, 4829-4832.

Calbet, M., Guadano-Ferraz, A., Spier, A.D., Maj, M., Sutcliffe, J.G., Przewlocki, R., de Lecea, L., 1999. Cortistatin and somatostatin mRNAs are differentially regulated in response to kainate. Brain Res.Mol.Brain Res. 72, 55-64.

Cammalleri, M., Cervia, D., Dal, M.M., Martini, D., Langenegger, D., Fehlmann, D., Feuerbach, D., Pavan, B., Hoyer, D., Bagnoli, P., 2006. Compensatory changes in the hippocampus of somatostatin knockout mice: upregulation of somatostatin receptor 2 and its function in the control of bursting activity and synaptic transmission. Eur.J.Neurosci. 23, 2404-2422. 
Cassoni, P., Allia, E., Marrocco, T., Ghe, C., Ghigo, E., Muccioli, G., Papotti, M., 2006. Ghrelin and cortistatin in lung cancer: expression of peptides and related receptors in human primary tumors and in vitro effect on the H345 small cell carcinoma cell line. J.Endocrinol.Invest 29, 781-790.

Dalm, V.A., Van Hagen, P.M., de Krijger, R.R., Kros, J.M., Van Koetsveld, P.M., Van Der Lely, A.J., Lamberts, S.W., Hofland, L.J., 2004. Distribution pattern of somatostatin and cortistatin mRNA in human central and peripheral tissues. Clin.Endocrinol.(Oxf) 60, 625-629.

deLecea, L., Castano, J.P., 2006. Cortistatin: not just another somatostatin analog. Nat.Clin.Pract.Endocrinol.Metab 2, 356-357.

deLecea.L., Criado, J.R., Prospero-Garcia, O., Gautvik, K.M., Schweitzer, P., Danielson, P.E., Dunlop, C.L., Siggins, G.R., Henriksen, S.J., Sutcliffe, J.G., 1996. A cortical neuropeptide with neuronal depressant and sleep-modulating properties. Nature 381, 242-245.

deLecea.L., del Rio, J.A., Criado, J.R., Alcantara, S., Morales, M., Danielson, P.E., Henriksen, S.J., Soriano, E., Sutcliffe, J.G., 1997a. Cortistatin is expressed in a distinct subset of cortical interneurons. J.Neurosci. 17, 5868-5880.

deLecea.L., Ruiz-Lozano, P., Danielson, P.E., Peelle-Kirley, J., Foye, P.E., Frankel, W.N., Sutcliffe, J.G., 1997b. Cloning, mRNA expression, and chromosomal mapping of mouse and human preprocortistatin. Genomics 42, 499-506.

Deghenghi, R., Avallone, R., Torsello, A., Muccioli, G., Ghigo, E., Locatelli, V., 2001a. Growth hormone-inhibiting activity of cortistatin in the rat. J.Endocrinol.Invest 24, RC31-RC33.

Deghenghi, R., Broglio, F., Papotti, M., Muccioli, G., Ghigo, E., 2003. Targeting the ghrelin receptor: orally active GHS and cortistatin analogs. Endocrine. 22, 13-18.

Deghenghi, R., Papotti, M., Ghigo, E., Muccioli, G., 2001b. Cortistatin, but not somatostatin, binds to growth hormone secretagogue (GHS) receptors of human pituitary gland. J.Endocrinol.Invest 24, RC1-RC3.

Engler, D., Redei, E., Kola, I., 1999. The corticotropin-release inhibitory factor hypothesis: a review of the evidence for the existence of inhibitory as well as stimulatory hypophysiotropic regulation of adrenocorticotropin secretion and biosynthesis. Endocr.Rev. 20, 460-500.

Fehm, H.L., Voigt, K.H., Lang, R., Beinert, K.E., Raptis, S., Pfeiffer, E.F., 1976. Somatostatin: a potent inhibitor of ACTH-hypersecretion in adrenal insufficiency. Klin.Wochenschr. 54, 173-175. 
Fukusumi, S., Kitada, C., Takekawa, S., Kizawa, H., Sakamoto, J., Miyamoto, M., Hinuma, S., Kitano, K., Fujino, M., 1997. Identification and characterization of a novel human cortistatin-like peptide. Biochem.Biophys.Res.Commun. 232, 157-163.

Giordano, R., Picu, A., Bonelli, L., Broglio, F., Prodam, F., Grottoli, S., Muccioli, G., Ghigo, E., Arvat, E., 2007. The activation of somatostatinergic receptors by either somatostatin-14 or cortistatin-17 often inhibits acth hypersecretion in patients with cushing's disease. Eur.J.Endocrinol.

Gottero, C., Prodam, F., Destefanis, S., Benso, A., Gauna, C., Me, E., Filtri, L., Riganti, F., Van Der Lely, A.J., Ghigo, E., Broglio, F., 2004. Cortistatin-17 and -14 exert the same endocrine activities as somatostatin in humans. Growth Horm.IGF.Res. 14, 382-387.

Grottoli, S., Gasco, V., Broglio, F., Baldelli, R., Ragazzoni, F., Gallenca, F., Mainolfi, A., Prodam, F., Muccioli, G., Ghigo, E., 2006. Cortistatin-17 and somatostatin-14 display the same effects on growth hormone, prolactin, and insulin secretion in patients with acromegaly or prolactinoma. J.Clin.Endocrinol.Metab 91, 1595-1599.

Kamohara, M., Matsuo, A., Takasaki, J., Kohda, M., Matsumoto, M., Matsumoto, S., Soga, T., Hiyama, H., Kobori, M., Katou, M., 2005. Identification of MrgX2 as a human G-protein-coupled receptor for proadrenomedullin N-terminal peptides. Biochem.Biophys.Res.Commun. 330, 11461152.

Lamberts, S.W., Krenning, E.P., Reubi, J.C., 1991. The role of somatostatin and its analogs in the diagnosis and treatment of tumors. Endocr.Rev. 12, 450-482.

Lamberts, S.W., Uitterlinden, P., Klijn, J.M., 1989. The effect of the long-acting somatostatin analogue SMS 201-995 on ACTH secretion in Nelson's syndrome and Cushing's disease. Acta Endocrinol.(Copenh) 120, 760-766.

Low, M.J., Otero-Corchon, V., Parlow, A.F., Ramirez, J.L., Kumar, U., Patel, Y.C., Rubinstein, M., 2001. Somatostatin is required for masculinization of growth hormone-regulated hepatic gene expression but not of somatic growth. J.Clin.Invest 107, 1571-1580.

Luque, R.M., Gahete, M.D., Hochgeschwender, U., Kineman, R.D., 2006a. Evidence that endogenous SST inhibits ACTH and ghrelin expression by independent pathways. Am.J.Physiol Endocrinol.Metab 291, E395-E403. 
Luque, R.M., Kineman, R.D., 2007. Gender-dependent role of endogenous somatostatin in regulating growth hormone-axis function in mice. Endocrinology 148, 5998-6006.

Luque, R.M., Peinado, J.R., Gracia-Navarro, F., Broglio, F., Ghigo, E., Kineman, R.D., Malagon, M.M., Castano, J.P., 2006b. Cortistatin mimics somatostatin by inducing a dual, dose-dependent stimulatory and inhibitory effect on growth hormone secretion in somatotropes. J.Mol.Endocrinol. $36,547-556$.

Moller, L.N., Stidsen, C.E., Hartmann, B., Holst, J.J., 2003. Somatostatin receptors. Biochim.Biophys.Acta 1616, 1-84.

Muccioli, G., Papotti, M., Locatelli, V., Ghigo, E., Deghenghi, R., 2001. Binding of 125I-labeled ghrelin to membranes from human hypothalamus and pituitary gland. J.Endocrinol.Invest 24, RC7RC9.

Papotti, M., Tarabra, E., Allia, E., Bozzalla-Cassione, F., Broglio, F., Deghenghi, R., Ghigo, E., Muccioli, G., 2003. Presence of cortistatin in the human pancreas. J.Endocrinol.Invest 26, RC15RC18.

Patel, Y.C., 1999. Somatostatin and its receptor family. Front Neuroendocrinol. 20, 157-198.

Ramirez, J.L., Mouchantaf, R., Kumar, U., Otero, C., V, Rubinstein, M., Low, M.J., Patel, Y.C., 2002. Brain somatostatin receptors are up-regulated in somatostatin-deficient mice. Mol.Endocrinol. 16, 1951-1963.

Robas, N., Mead, E., Fidock, M., 2003. MrgX2 is a high potency cortistatin receptor expressed in dorsal root ganglion. J.Biol.Chem. 278, 44400-44404.

Rubinfeld, H., Hadani, M., Barkai, G., Taylor, J.E., Culler, M.D., Shimon, I., 2006. Cortistatin inhibits growth hormone release from human fetal and adenoma pituitary cells and prolactin secretion from cultured prolactinomas. J.Clin.Endocrinol.Metab 91, 2257-2263.

Sibilia, V., Muccioli, G., Deghenghi, R., Pagani, F., De, L., V, Rapetti, D., Locatelli, V., Netti, C., 2006. Evidence for a Role of the GHS-R Receptors in Ghrelin Inhibition of Gastric Acid Secretion in the Rat. J.Neuroendocrinol. 18, 122-128.

Smith, R.G., Leonard, R., Bailey, A.R., Palyha, O., Feighner, S., Tan, C., McKee, K.K., Pong, S.S., Griffin, P., Howard, A., 2001. Growth hormone secretagogue receptor family members and ligands. Endocrine. 14, 9-14. 
Spier, A.D., de, L.L., 2000. Cortistatin: a member of the somatostatin neuropeptide family with distinct physiological functions. Brain Res.Brain Res.Rev. 33, 228-241.

Stalla, G.K., Brockmeier, S.J., Renner, U., Newton, C., Buchfelder, M., Stalla, J., Muller, O.A., 1994. Octreotide exerts different effects in vivo and in vitro in Cushing's disease. Eur.J.Endocrinol. $130,125-131$.

Stumm, R.K., Zhou, C., Schulz, S., Endres, M., Kronenberg, G., Allen, J.P., Tulipano, G., Hollt, V., 2004. Somatostatin receptor 2 is activated in cortical neurons and contributes to neurodegeneration after focal ischemia. J.Neurosci. 24, 11404-11415.

Tostivint, H., Lihrmann, I., Bucharles, C., Vieau, D., Coulouarn, Y., Fournier, A., Conlon, J.M., Vaudry, H., 1996. Occurrence of two somatostatin variants in the frog brain: characterization of the cDNAs, distribution of the mRNAs, and receptor-binding affinities of the peptides. Proc.Natl.Acad.Sci.U.S.A 93, 12605-12610.

Tyrrell, J.B., Lorenzi, M., Gerich, J.E., Forsham, P.H., 1975. Inhibition by somatostatin of ACTH secretion in Nelson's syndrome. J.Clin.Endocrinol.Metab 40, 1125-1127.

Van Der Lely, A.J., Tschop, M., Heiman, M.L., Ghigo, E., 2004. Biological, physiological, pathophysiological, and pharmacological aspects of ghrelin. Endocr.Rev. 25, 426-457.

Xidakis, C., Mastrodimou, N., Notas, G., Renieri, E., Kolios, G., Kouroumalis, E., Thermos, K., 2007. RT-PCR and immunocytochemistry studies support the presence of somatostatin, cortistatin and somatostatin receptor subtypes in rat Kupffer cells. Regul.Pept.

Zeyda, T., Diehl, N., Paylor, R., Brennan, M.B., Hochgeschwender, U., 2001. Impairment in motor learning of somatostatin null mutant mice. Brain Res. 906, 107-114. 